\title{
ARISTÓTELES E SEUS PRECURSORES. PARA UMA ARQUEOLOGIA DO DISCURSO DELIBERATIVO
}

\author{
LAURENT PERNOT* \\ Université de Strasbourg II \\ (Strasbourg, França)
}

\begin{abstract}
RESUMO: Estudam-se aqui as origens da classificação dos gêneros de discurso (gênero deliberativo, gênero judiciário, gênero epidítico) tal como a apresenta Aristóteles na Retórica, e particularmente o que concerne à definição do gênero deliberativo em relação aos outros gêneros. Para esse fim são examinados textos de Tucídides, Platão, Isócrates e da Retórica a Alexandre, nos quais aparecem classificações e critérios que prefiguram os de Aristóteles. Essa investigação permite reconstituir o contexto intelectual da Retórica e compreender melhor a maneira como Aristóteles trabalhou para compor esse tratado, operando uma sistematização a partir de noções e de problemas preexistentes.
\end{abstract}

PALAVRAS-CHAVE: gêneros de discurso; gênero deliberativo; Retórica de Aristóteles.

Aristóteles, na Retórica, conceptualizou a deliberação, apresentando-a sob o nome de "gênero deliberativo" ( $\sigma u \mu \beta ం v \lambda \varepsilon v \tau \imath \kappa o ̀ v ~ \gamma \varepsilon ́ v o \varsigma)$, como uma classe de discursos retóricos, distinta das outras classes e definida por características técnicas. Nas páginas que seguem, trata-se, a partir do texto aristotélico, de remontar no tempo e de localizar os afloramentos de uma conceptualização análoga à de Aristóteles em textos anteriores a este. $\mathrm{O}$ objetivo desta pequena investigação não é procurar fontes, mas tentar compreender como Aristóteles trabalhou na Retórica, como ele construiu uma classificação nova sobre a base de elementos que preexistiam no pensamento grego dos $V^{o}-I V o$ séculos a. C. Tentaremos fazer de certo modo uma arqueologia da conceptualização aristotélica.

Dada a dimensão deste artigo, a investigação será limitada e terá por objeto somente uma seleção de textos que apresentam uma relação com a retórica e que 
datam do fim do $V^{o}$ e do IVo século, concentração que apresenta a vantagem de constituir um corpus coerente e próximo, intelectualmente e cronologicamente, da Retórica de Aristóteles. Não esqueçamos, para tanto, que a deliberação foi analisada também, entre outras, nas obras dos poetas (épicos, trágicos, cômicos) e nas obras filosóficas (por exemplo, por Aristóteles mesmo na Ética a Nicômaco, III, 5, e VI, 10), e que ela foi uma prática política e institucional amplamente difundida. A dificuldade de pensar retoricamente a deliberação, para Aristóteles como para seus precursores, consistia precisamente em reduzir a uma análise simples um fenômeno onipresente, multiforme e já abundantemente discutido.

\section{Aristóteles}

Admite-se geralmente que a Retórica foi composta no curso do segundo terço do IVo século. No início do tratado (I, 3), Aristóteles traça uma divisão dos discursos retóricos em três gêneros: o deliberativo, o judiciário, o epidítico. Cada um desses gêneros é definido por uma série de critérios: o ouvinte ao qual ele se dirige, seu conteúdo, o tempo que ele tem em vista, o seu fim. Mais adiante (III, 12) é acrescentada uma definição segundo o estilo. Procedendo por raciocínios e afirmações, Aristóteles constrói um sistema tripartite, acompanhado de uma terminologia, com tal rigor que a classificação pode ser resumida por um quadro (cf. infra).

Esse sistema, muito ambicioso, já que reduz somente a três categorias todos os discursos possíveis, veio a conhecer um imenso sucesso e a servir de referência universal para a classificação dos gêneros oratórios durante a Antigüidade. Ora, da maneira como Aristóteles a apresenta, a classificação aparece como dada logo à primeira, sem referência a nenhuma doutrina anterior sobre a questão. $O$ autor expõe o seu pensamento como filósofo, em nome de uma análise teórica das condições da persuasão, tal como esta se exerce no quadro dos usos e das instituições. Poder-se-ia ter, pois, a impressão, ao ler a Retórica, de que a tripartição dos gêneros é uma inovação radical, nascida inteiramente armada da cabeça do Estagirita. Nossa hipótese é de que as coisas não se passaram assim - o que não diminui de modo algum o mérito de Aristóteles - e de que o quadro aristotélico havia sido preparado pelas reflexões de pensadores anteriores. 


\begin{tabular}{|c|c|c|c|c|c|}
\hline & $\begin{array}{l}\text { papel do ouvinte } \\
\left(\alpha \alpha \kappa \rho \circ \alpha \tau \varsigma^{\prime}\right)\end{array}$ & conteúdo & 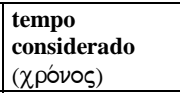 & $\begin{array}{l}\text { fim } \\
\left(\tau \tau^{\prime} \lambda \supset \varsigma\right)\end{array}$ & $\begin{array}{l}\text { estilo } \\
(\lambda \varepsilon \xi \xi \varsigma)\end{array}$ \\
\hline $\begin{array}{l}\text { gênero deliberativo } \\
(\sigma \nu \mu \beta ం v \lambda \varepsilon v \tau t \kappa o ̀ v \\
\gamma(\varepsilon \nu \circ \varsigma)\end{array}$ & 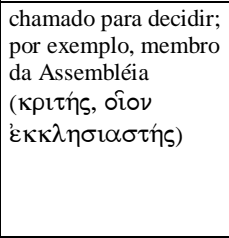 & 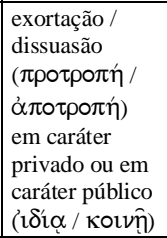 & $\begin{array}{l}\text { futuro } \\
(\mu \varepsilon \lambda \lambda \omega \nu)\end{array}$ & 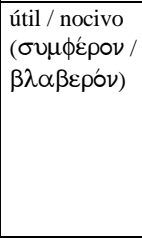 & $\begin{array}{l}\text { estilo dos } \\
\text { debates } \\
(\dot{\alpha} \gamma \omega \nu 1 \sigma \tau 1 \\
\kappa \dot{)})\end{array}$ \\
\hline $\begin{array}{l}\text { gênero judiciário } \\
\left(\delta 1 \kappa \alpha \nu ı \text { kò } \gamma^{\prime} \varepsilon \nu \circ \varsigma\right)\end{array}$ & 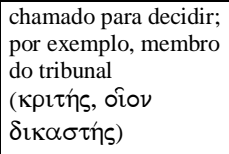 & $\begin{array}{l}\text { acusação / } \\
\text { defesa } \\
(\kappa \alpha \tau \eta \gamma o p i ́ \alpha \text { / } \\
\dot{\alpha} \pi \circ \lambda \circ \gamma^{\prime}(\alpha)\end{array}$ & $\begin{array}{l}\text { passado } \\
(\gamma \varepsilon v o ́ \mu \varepsilon v o \varsigma)\end{array}$ & 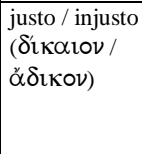 & $\begin{array}{l}\text { estilo dos } \\
\text { debates } \\
\left(\dot{\alpha} \gamma \omega \nu \imath \_\tau \iota\right. \\
\kappa \dot{n})\end{array}$ \\
\hline 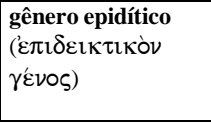 & $\begin{array}{l}\text { espectador } \\
\left(\theta \varepsilon \omega \rho \varsigma^{\prime}\right)\end{array}$ & 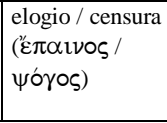 & 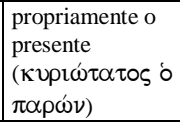 & 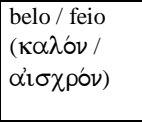 & $\begin{array}{l}\text { estilo do } \\
\text { escrito } \\
\text { ( } \gamma \rho \propto \phi \iota \dot{~})\end{array}$ \\
\hline
\end{tabular}

\section{Tucídides}

No livro III de Tucídides, a célebre antilogia que opõe Cleão e Diódoto apresenta um grande interesse não somente para a história das idéias políticas e para a história simplesmente, mas também para a história da retórica. Em 427 a. C., após uma primeira assembléia que havia decidido castigar duramente os mitilenenses, culpados de se terem rebelado contra a dominação ateniense, a questão foi reexaminada no dia seguinte numa segunda assembléia, durante a qual Cleão se pronunciou pela manutenção do castigo decidido, Diódoto, ao contrário, por um abrandamento da pena. Diódoto venceu e os atenienses enviaram logo a Mitilene uma trirreme para anular a ordem de condenação à morte notificada na véspera. Esse episódio constitui, ao ver de Tucídides, a matéria de uma reflexão implícita sobre o que deve ser a deliberação política. O processo de Mitilene oferece o exemplo de uma deliberação pervertida, que se opõe particularmente ao exemplo de boa deliberação, esclarecida por bons conselheiros, que é dado no livro I, 139-145, por ocasião do debate, conduzido por Péricles, sobre a resposta a dar ao ultimato espartano.

No caso do debate sobre Mitilene, em lugar de vermos jogar somente os mecanismos da inteligência e da previdência $(\gamma \nu \omega \mu \eta, \pi \rho o ́ v 01 \alpha)$, assistimos a um desencadeamento de paixões: "cólera", "ardor" durante a primeira assembléia (36, 2:

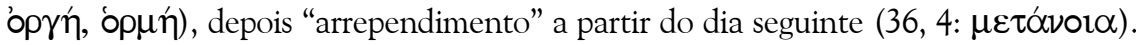
Exercem-se influências exteriores, com as pressões dos embaixadores mitilenenses e dos seus partidários atenienses. Enfim o resultado mesmo do debate é submetido ao 


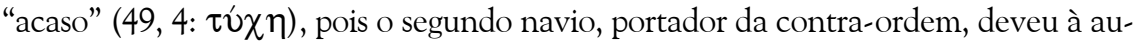
sência de vento contrário a possibilidade de compensar o seu atraso sobre o primeiro e de chegar antes que a ordem de condenação à morte tivesse começado a ser executada. Tudo acabou como devia, no sentido de que a segunda decisão pôde ser aplicada; Atenas (e Mitilene) haviam somente roçado a catástrofe; mas se a haviam roçado, é porque a deliberação havia sido mal conduzida.

Ora, a essa demonstração implícita se acrescentam reflexões explícitas, contidas nas palavras de Cleão e de Diódoto diante da segunda assembléia. Os oradores comentam o debate do qual participam e definem a direção que deve tomar segundo eles a deliberação, empenhando-se em distinguir o discurso deliberativo das formas oratórias concorrentes.

Cleão opõe a verdadeira deliberação a uma prática ateniense que é não é senão um simulacro de deliberação: um debate ( $\alpha \gamma(\omega \nu)$, mas para exibição, no qual os ouvintes são "espectadores de palavras" ( $\theta \varepsilon \alpha \tau \alpha i \tau \omega \hat{\omega} \nu \lambda \hat{o} \gamma \omega \nu)$,

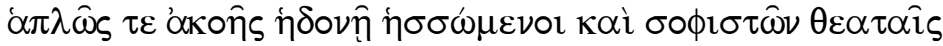

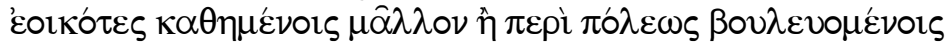 (III, 38, 7)}

numa palavra, pessoas dominadas pelo prazer de escutar, semelhantes a um público posto lá mais para o espetáculo de sofistas do que como cidadãos que deliberam sobre a sua cidade.

Seguramente, essas palavras são perfeitamente cínicas e relevam de uma tática de circunstância. Descontente de ver ser recolocada na ordem do dia uma questão já resolvida, Cleão critica as deliberações atenienses em geral, porque não queria que essa deliberação particular acontecesse; e ele não hesita em formular suas censuras contra os sofistas em um estilo eminentemente sofístico, de maneira a utilizar em proveito próprio a arte de agradar que ele repreende nos outros. Entretanto, para além dos móveis circunstanciais do demagogo, a opinião expressa é importante. Cleão denuncia a irresponsabilidade popular, que transforma o debate político em exibição sofística. Ele denuncia a política-espetáculo, por assim dizer, e para esse fim opõe o discurso deliberativo ao discurso sofístico, tomando como critério principal o papel do ouvinte, que num caso "delibera" (ßov $\lambda \varepsilon v ́ \varepsilon \sigma \theta \alpha \imath$ ) e no outro é "espectador"

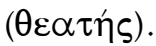

Diódoto, de sua parte, opõe deliberação e julgamento, para indicar que o debate em curso não deve tomar a forma de um debate judiciário. Operando uma espécie 
de sobrelanço no realismo, em relação ao discurso de Cleão, Diódoto quer ter em vista apenas a utilidade, com exclusão de qualquer outra consideração. Não se trata, pois, de julgar os mitilenenses em nome do direito, mas de tomar um partido vantajoso a seu respeito. Com uma formidável insistência de vocabulário, Diódoto sublinha que os

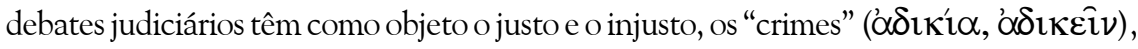

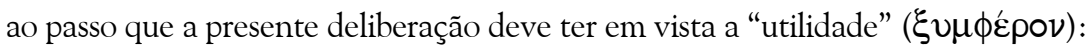

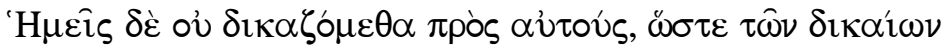

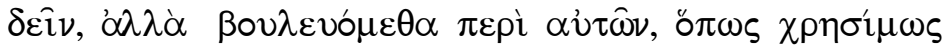

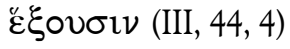

Nós não movemos um processo contra eles, e não nos importamos com argumentos de direito: nós deliberamos sobre eles, querendo que eles nos sejam úteis.

Quando atentamos para as duas passagens, vemos, então, a deliberação se opor, de um lado, ao discurso dos sofistas, de outro, ao debate judiciário. Mesmo se os dois oradores se afrontam e rivalizam, a antilogia tomada em seu conjunto sugere uma tripartição coerente, e essa tripartição evoca fortemente a tripartição aristotélica dos gêneros de discurso, ainda mais que ela se apóia sobre critérios (papel do ouvinte, fim do discurso) e sobre uma terminologia que se reencontram em Aristóteles. Certamente, as duas classificações não coincidem exatamente: em particular, o discurso sofístico considerado por Cleão corresponde apenas parcialmente ao gênero epidítico de Aristóteles, pois faltam na definição de Cleão as noções de elogio e de censura que são essenciais para Aristóteles. No entanto é impressionante a semelhança nas grandes linhas.

Como apreciar essa constatação? É preciso nos preservarmos do raciocínio anacrônico que revestiria com o esquema aristotélico o texto de Tucídides. De fato, não se trata de compreender os textos tucididianos por meio de Aristóteles, mas, ao contrário, de compreender Aristóteles por meio dos textos tucididianos. Pode-se, a partir daí, concluir que o sistema aristotélico teve pródromos e que a idéia de uma classificação dos gêneros oratórios, tendente a uma tripartição, em função de diferentes critérios, existia em Atenas desde a época de Tucídides, mesmo se se tratasse então, certamente, apenas de uma classificação entre outras. A data de referência é impossível de fixar: talvez 427, se tais discursos foram efetivamente realizados por Cleão e Diódoto, ou então a virada do № e do IVo século, se foram introduzidos por Tucídides na sua reescritura dos discursos. 


\section{Platão}

Numerosos são os textos de Platão que propõem divisões das formas de discursos, da mesma maneira que, noutros lugares, o filósofo esboça, por exemplo, divisões das formas poéticas. Como justamente observou A. Hellwig, Platão, nesse caso, não procura preparar classificações exaustivas, mas se contenta em distinguir os elementos úteis para a sua demonstração do momento. Entre esses esboços de taxinomia, um excerto do Fedro merece ser examinado em relação com o sistema aristotélico.

Na parte final do diálogo, dedicada às relações entre retórica e filosofia, Sócrates propõe uma definição da retórica:

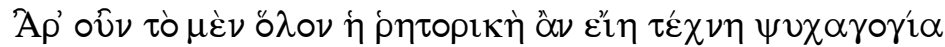

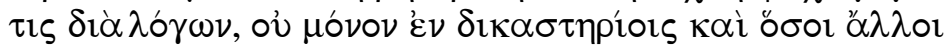

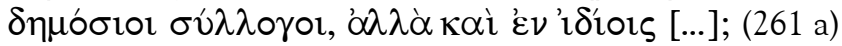

Não seria a retórica em geral uma psicagogia - uma arte de conduzir as almas - que se exerce pela palavra, não somente nos tribunais e em todas as outras assembléias públicas, mas ainda nas reuniões privadas [...]?

Nessa definição, o gênero judiciário está bem isolado, ao passo que as outras situações de fala estão reunidas, sem especificação, sob a qualificação de "assembléias públicas", o que pode incluir tanto os discursos dirigidos à Assembléia e ao Conselho quanto os discursos fúnebres pronunciados no Cerâmico. Mas o interesse particular desse texto está em que ele introduz, ao lado das alocuções públicas, discursos pronunciados num espaço privado.

Sócrates postula uma unidade fundamental da retórica e afirma que esta permanece fundamentalmente a mesma, que ela se exerce em caráter privado ou público, ou ainda (isso é acrescentado nas linhas seguintes) que ela tem como objeto pequenos ou grandes assuntos, assuntos sérios ou assuntos fúteis. Quintiliano, leitor atento de Platão, viu bem qual era o acento da passagem:

In Phaedro palam non in iudiciis modo et contionibus, sed in rebus etiam prinatis ac domesticis rhetoricen esse demonstrat (Instituição oratória, II, 21, 4)

No Fedro, ele [Sócrates] mostra abertamente que a retórica não intervém somente no tribunal e nas assembléias, mas também nos processos privados e domésticos. 
Pode-se, então, estabelecer uma aproximação entre o texto platônico e as passagens em que Aristóteles indica, a propósito do gênero deliberativo, que a retórica se dirige quer a um público coletivo, quer a um único ouvinte.

Essa aproximação é completada por um outro tema, que aparece na resposta de Fedro a Sócrates:

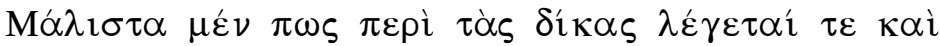

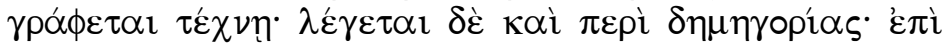

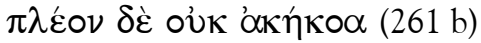

É sobretudo nos processos que a fala e o escrito se fundam numa arte; entretanto, fala-se também nas assembléias do povo. Mas eu não ouvi dizer que essa arte se estendesse mais longe.

Graças a essa réplica, a classificação dos discursos se enriquece com um critério suplementar: o uso do oral ou do escrito. Para Fedro, a demegoria se define como discurso oral, ao passo que o discurso judiciário é oral ou escrito. Ora, Aristóteles utiliza esse mesmo critério no livro III da Retórica (capítulo 12). Aparentemente, a aplicação do critério não é a mesma nos dois casos, já que em Platão o escrito é mencionado a propósito do gênero judiciário, ao passo que no sistema aristotélico é o epidítico que é do domínio do escrito, competindo o deliberativo e o judiciário ao estilo dos debates. Entretanto, se examinamos o texto aristotélico mais de perto, percebemos que o autor traça uma gradação nuançada entre o estilo das demegorias, que pertence puramente ao debate, e o estilo judiciário, que admite mais "exatidão" ('okpí $\beta \varepsilon \imath \alpha)$ e se aproxima do estilo escrito. A concordância entre Platão e Aristóteles, sobre esse ponto, vai, pois, mais longe do que parece à primeira vista. De resto, essas indicações estão em conformidade com as realidades materiais e institucionais da Atenas clássica, na qual os discursos de assembléia foram rara e tardiamente submetidos à escrita, ao passo que os discursos judiciários, seria apenas por causa da prática da logografia, necessitavam mais freqüentemente da redação de um texto.

Fedro precisa que o que ele aí relata, ele "ouviu dizer" ( $\alpha \kappa \eta \dot{\eta} \kappa о \alpha)$. Ele se refere

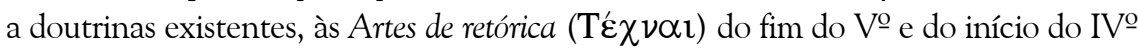
século, tais como são descritas um pouco mais adiante no diálogo ( $266 \mathrm{~d}-267 \mathrm{~d})$. As indicações de Platão não são pura invenção, mas se apóiam sobre pesquisas de retores e de sofistas, pesquisas que Tucídides, pode-se suspeitar, também conhecia, e que

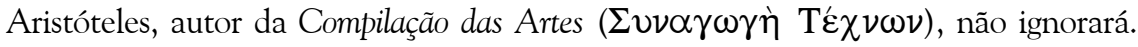
Uma arqueologia da Retórica de Aristóteles deve levar em conta a existência dessas T'́́ $\chi \propto \alpha \iota$ hoje desaparecidas. 
Se o texto do Fedro não isola o gênero deliberativo como tal, ele utiliza, então, critérios e enuncia distinções que se reencontram em Aristóteles a propósito da tripartição dos gêneros e do gênero deliberativo em particular (e que não são os mesmos critérios e distinções que figuram em Tucídides). Ainda aqui, pode-se falar de preparação e de pródromos da sistematização aristotélica. Ainda aqui, a datação é incerta, pois varia conforme relacionamos os discursos realizados à data dramática do diálogo (418-416 a. C.) ou à sua data de composição (por volta de 370 a. C.).

A convergência entre Platão e Aristóteles é ainda mais significativa diante do fato de que, sob outro aspecto, a passagem platônica obedece a objetivos específicos, ligados à problemática mesma do Fedro: a saber, a reivindicação da conversa privada (e portanto do diálogo) em benefício da verdadeira retórica e a reflexão sobre oralidade e escrita. A classificação dos gêneros de discurso é como um substrato retórico no método filosófico do Fedro.

\section{Isócrates}

Durante uma longa vida dedicada à eloqüência, Isócrates efetuou uma espécie de percurso através das formas retóricas, definindo sucessivamente diferentes categorias de discurso e posicionando-se em relação a elas. A história desse percurso, que foi complexo, está por escrever. Seria uma contribuição considerável para o conhecimento, não somente do pensamento de Isócrates, mas ainda da história da retórica no IVo século. Contentemo-nos aqui em marcar algumas balizas.

Após haver praticado a eloqüência judiciária, Isócrates a abandonou em proveito dos grandes temas "helênicos e políticos". Ele explicou, no Panegírico, uma forma oratória que consistia em conselhos baseados no elogio e formulados num estilo rebuscado. Paralelamente - prova suplementar de seu interesse pela teoria dos gêneros retóricos -, traçou uma demarcação entre elogio e apologia (Elogio de Helena) e introduziu o elogio de contemporâneo em prosa (Evágoras). Enfim, no último período de sua vida, defendeu uma nova concepção do conselho, que tendia a desligar este do elogio, da epideixis e do belo estilo, em nome da eficácia, e que pela mesma razão privilegiava o conselho endereçado a um destinatário único, a um soberano, por exemplo, de preferência ao conselho endereçado ao povo. A oposição entre este conselho puro, sóbrio e individualizado e o conselho encomiástico, ornado e coletivo de outrora é resumida pela diferença que separa o Felipe do Panegírico. Fazendo ressaltar os planos da deliberação política tradicional, concebida como a desenrolar-se numa assembléia, Isócrates havia outrora, à época do Panegírico, proposto um debate ampliado, tencio- 
nando agir sobre a opinião; presentemente, com o Felipe, ele propunha um debate restrito, querendo fazer-se o conselheiro do príncipe. Nesta última etapa, Isócrates isolou o conselho com uma nitidez que faz eco à definição aristotélica do gênero deliberativo.

Essa evolução pode ter sido determinada, entre outras, pelas críticas que tinham sido formuladas contra o Panegírico, para censurá-lo como um discurso inútil e que valia unicamente pela forma. Essas críticas não foram conservadas: ainda aqui, há que se tomar consciência da existência de balizas perdidas na reflexão sobre os gêneros oratórios.

Menos conhecida que o Felipe, e anterior a ele em dez anos, mas igualmente reveladora, é uma passagem da Carta IX, A Arquidamo (356 a. C.), que apresenta a mesma doutrina. Endereçando-se a Arquidamo, Isócrates indica que seria fácil louválo, a ele e a seus antepassados - e, dizendo isso, faz-lhe um cumprimento não desprovido de elegância. Mas, prossegue, tal não é o caminho que ele escolheu nessa carta:

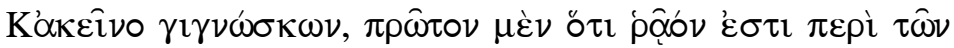

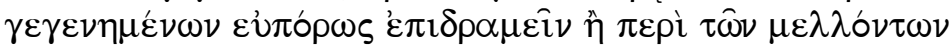

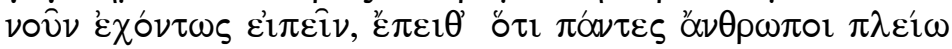

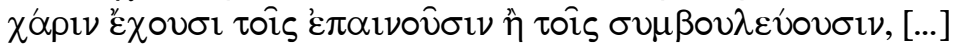

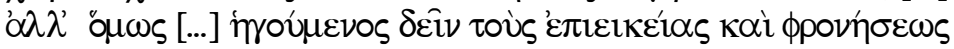

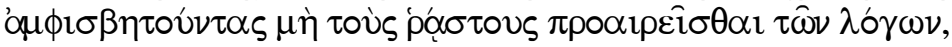

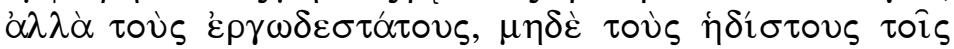

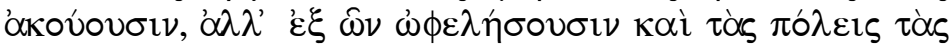

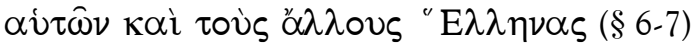

Eu reconhecia, antes de mais nada, que é mais fácil expor abundantemente o passado que falar razoavelmente do futuro, e, depois, que todo o mundo sabe melhor graças aos autores de elogios que aos distribuidores de conselhos [...]; no entanto, a meu ver, aqueles que pretendem possuir qualidades morais e inteligência, devem escolher, não os discursos mais fáceis, senão que os mais dificultosos, não os mais agradáveis aos ouvintes, mas aqueles pelos quais eles prestarão serviço à sua pátria e ao resto da Grécia.

Nesse texto, o conselho se opõe ao elogio como a dificuldade à facilidade, a utilidade ao prazer, o futuro ao passado. As idéias e a terminologia podem ser aproximadas daquelas de Aristóteles. 
Mais próxima ainda da Retórica de Aristóteles é uma frase do Sobre a paz, datada igualmente de 356 a. C., em que se reencontram exatamente três termos que servirão para designar os três gêneros:

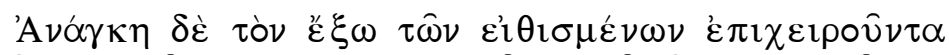

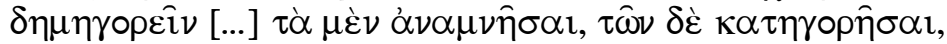

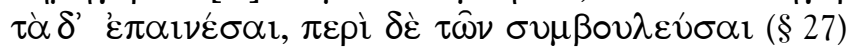

Necessariamente, quem tenta falar ao povo numa linguagem fora de seus hábitos [...] deve [...] ora lembrar as coisas, ora acusar, ora louvar, ora aconselhar.

A tripartição é aqui muito clara, com a reserva, todavia, de que um quarto elemento

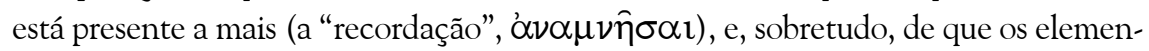
tos enumerados não constituem gêneros de discurso, mas formas internas ao discurso.

\section{A Retórica a Alexandre}

Assinalaremos enfim, sem poder examiná-lo em detalhe, o tratado pseudoaristotélico intitulado Retórica a Alexandre, que apresenta um sistema estreitamente semelhante ao da Retórica de Aristóteles:

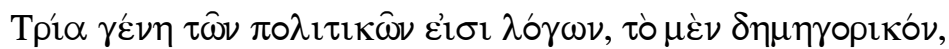

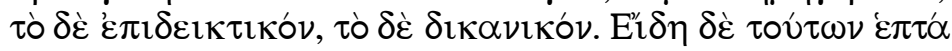

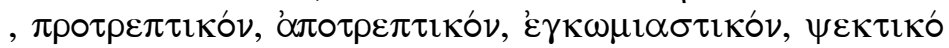

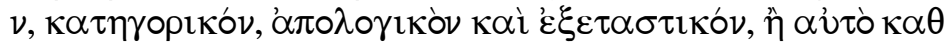

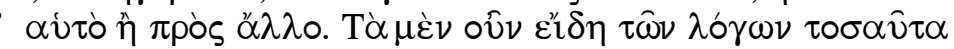

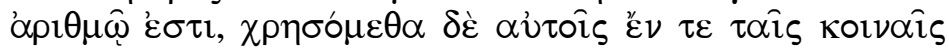

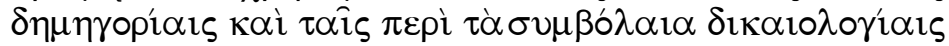

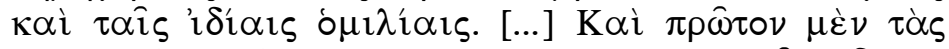

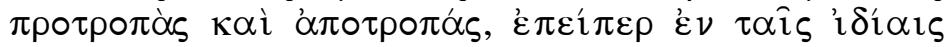

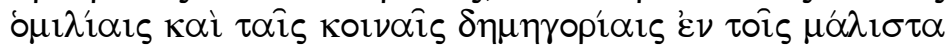

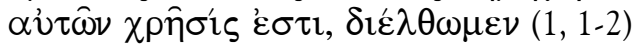

Há três gêneros de discursos políticos: o demegórico, o epidítico, o judiciário. Suas espécies são sete: exortação, dissuasão, elogio, censura, acusação, defesa e exame, seja por si mesmo, seja referido a uma outra espécie. Aí está, pois, o número das espécies de discursos: empregá-los- 
emos nas demegorias públicas, nos discursos em justiça relativos aos contratos e nas conversas privadas. [...] E tratemos, primeiramente, das exortações e dissuasões, já que o seu emprego é dos mais freqüentes nas conversas privadas e nas demegorias públicas.

A conformidade com a doutrina aristotélica é estreita, tanto para a definição dos três gêneros quanto para a inclusão de uma forma privada na definição do conselho. Toda a dificuldade é saber como interpretar essa conformidade. Os eruditos estimaram ora que a Retórica a Alexandre era anterior à Retórica de Aristóteles, ora que lhe era posterior, ora que a composição das duas obras, mais ou menos estendida no tempo, havia acontecido durante um mesmo período; ora que a Retórica a Alexandre havia sido influenciada pela Retórica, ora que era independente dela, e até que podia ter havido aí influências recíprocas. $\mathrm{O}$ texto mesmo que nos interessa foi suspeitado pelos editores, que pensaram que ele havia sido alinhado ao de Aristóteles e que era preciso, para reencontrar o estado original, seja atetizar toda referência aos três gêneros e conservar apenas a lista de sete espécies (Fuhrmann), seja atetizar a menção do gênero epidítico e corrigir $\tau p i ́ \alpha$ em $\delta v ́ o$ a fim de conservar apenas dois gêneros (Spengel).

Sobre a classificação dos gêneros, a Retórica a Alexandre levanta mais questões do que resolve. Força é mantê-la à margem da investigação, malgrado a tenhamos, porque ela autoriza conclusões contraditórias segundo a maneira como a interpretamos e eventualmente como a corrigimos.

O problema colocado pela Retórica a Alexandre e o desaparecimento de numerosos textos devem incitar à prudência. Não se pode afirmar, como F. Solmsen fez antigamente sem prova coerciva, que a tripartição dos gêneros existia antes de Aristóteles e que este nada fez senão impô-la com sua autoridade. Mas nos preservaremos igualmente de acreditar, como é o caso de numerosos intérpretes, que Aristóteles inventou essa tripartição inteiramente.

De fato, os textos que examinamos sugerem uma conclusão diferente. Eles convidam a deixar de lado, como simplista, a pesquisa de um "primeiro inventor", e a examinar antes a maneira como Aristóteles trabalhou. Percebemos, então, que Aristóteles operou ao mesmo tempo uma síntese e uma sistematização, propondo uma reclassificação das noções e dos critérios que haviam sido debatidos em Atenas durante pelo menos duas gerações. Para compreender bem a Retórica, é necessário reconstituir esse contexto intelectual, de que a exposição do Estagirita, ao contrário, faz mais freqüentemente abstração.

Essa conclusão particular conduz a implicações metodológicas mais amplas. Ela mostra que a Retórica de Aristóteles era um resultado tanto como uma criação, e, 
para além de Aristóteles, que a teoria retórica do meio e do fim do IVoo século, longe de constituir uma novidade radical, inscrevia-se num processo de elaboração gradual e num sistema de ecos e de debates que remontava ao início do IVo século e muito provavelmente já ao fim do №. Para quem se interroga sobre o desenvolvimento da retórica grega, o exemplo do gênero deliberativo é esclarecedor. Ele mostra que as noções de invenção e de inovação não dão conta de todos os aspectos, que não convém exagerar a parte das rupturas e que é preciso procurar, a cada momento, retraçar o encaminhamento dos problemas, em sua continuidade e complexidade: numa palavra, que convém considerar a retórica na sua plena evolução histórica.

Tradução integral

MARCELO VIEIRA FERNANDES** Faculdade de Filosofia, Letras e Ciências Humanas da Universidade de São Paulo

\section{Notas}

* Professor Doutor de Língua e Literatura Grega da Université de Strasbourg II e Diretor do Instituto de Grego Marc Bloch.

** Mestrando em Latim do Programa de Pós-Graduação em Letras Clássicas da FFLCHUSP.

1 Ver a esse respeito F. Ruze, Délibération et pouvoir dans la cité grecque de Nestor à Socrate, Paris, 1997. - Salvo menção contrária, remetemos, para os diferentes autores antigos, ao texto e à tradução (ligeiramente modificada em certos pontos) da Collection des Universités de France. - A questão que nos interessa aqui não é tratada nas dissertações clássicas de J. KLEK, Symbuleutici qui dicitur sermonis historia critica, Kirchhain N.-L., 1919; I. BECK, Untersuchungen zur Theorie des Genos symbuleutikon, Hambourg, 1970.

2 Ver G. A. Kennedy, Aristotle "On Rhetoric", New York - Oxford, 1991, Apêndice II A, p. 299-305.

3 Podemos deixar de lado os assuntos, lugares, planos e tipos de argumentos próprios a cada gênero, dos quais Aristóteles faz o exame detalhado na seqüência do tratado.

4 Uma análise esclarecedora desse capítulo complexo foi apresentada recentemente por M. S. Celentano, "Oralità, scrittura e modalità espressive (Aristotele, Rhetorica, III, 12)", comunicação no seminário Pour une nouvelle traduction de la "Rhétorique" d'Aristote, Paris, E.N.S., 19 de maio de 2000 (a publicar).

5 Cf. L. Pernot, La rhétorique de l'éloge dans le monde gréco-romain, Paris, 1993, p. 25-42. 
6 Ver em geral F. Frazier, "Réunion et délibération. La représentation des assemblées chez Thucydide", Ktèma, 22, 1997, p. 239-255.

7 Uma idéia semelhante aparecerá em Demóstenes, Prólogos, 33 (34), 2. Ver também Embaixada, 217; Coroa, 226.

8 Há igualmente diferenças no que concerne ao critério do tempo que cada tipo de discurso tem em vista.

9 Ver, para as formas de discurso, Górgias, 452 d-e; República, II, 365 d; Sofista, 222 c-d. A algumas passagens do Fedro e do Sofista é possível aproximar Alcidamante, Sobre os discursos escritos, 9-10.

10 Untersuchungen zur Theorie der Rhetorik bei Platon und Aristoteles (Hypomnemata, 38), Göttingen, 1973, p. 116.

11 Sobre a retórica no Fedro, ver, entre uma abundante bibliografia, vários artigos no importante volume Understanding the "Phaedrus" (Proceedings of the Second Symposium Platonicum), ed. L. Rossetti, Sankt Augustin, 1992.

12 Retórica, I, 3, 1358 b 9-10: "Tanto aqueles que dão um conselho em prol dum interesse

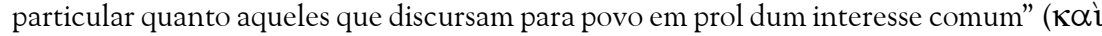

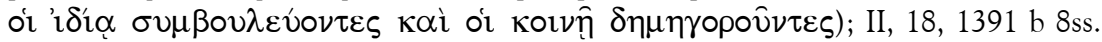
Sobre os problemas colocados pelas categorias do "privado" e da "conversa" em retórica ('iolos, ó $\mu \imath \lambda \mathfrak{i} \alpha, \pi \rho \circ \sigma o \mu \imath \lambda \eta \tau \imath \kappa \eta ́)$, ver as atas da mesa-redonda Rhétoriques de la conversation, ed. L. Pernot, Rhetorica, 11, 1993, n. 4 (p. 428-429 para os nossos comentários sobre os textos de Platão).

13 Retórica, III, 12, 1414 a 8-19.

14 Para essas datas, ver L. Brisson, Platon, "Phèdre", Paris, 1989, p. 32-34.

15 Sobre esse percurso de Isócrates, ver principalmente Elogio de Helena, 14-15; Panegírico, 1 18, 187-189; Evágoras, 5-11; Felipe, 1-18, 27-28; Panatenaico, 1-4, 263, 271; Cartas, I, 6; II, $1-2 ; \mathrm{VI}, 6$.

16 Cf. Troca, 62; Felipe, 4.

17 Levando em conta as presentes observações sobre a classificação dos gêneros, é importante, nessa passagem, traduzir kathgorh'sai por "acusar" (termo judiciário), e não por "censurar" [N.T.: "blamer"], como fez G. Mathieu na Collection des Universités de France (C.U.F.).

18 Texto de M. Fuhrmann, Anaximenis ars rhetorica quae vulgo fertur Aristotelis ad Alexandrum (Bibliotheca Teubneriana), Leipzig, 1966; a tradução é nossa.

19 Para essas atéteses, ver o prefácio da ed. FuHrmann, p. XL-XLI.

20 "The Aristotelian Tradition in Ancient Rhetoric", AJPh, 62 (1941), p. $42-43$ e 180-181. Solmsen baseava-se particularmente em Diógenes Laércio, III, 93, que atribui a Platão uma divisão dos discursos oratórios em seis espécies (exortação-dissuasão, acusação-defesa, elogio-censura); mas nenhuma passagem do corpus platônico apresenta essa divisão, e o fiador citado por Diógenes não é outro senão... Aristóteles (de fato Pseudo-Aristóteles). Sobre a dúvida que convém observar com relação à reconstrução apresentada por Diógenes Laércio, ver a introdução de L. BRISSON ao livro III em Diogène Laërce, "Vies et doctrines des 
philosophes illustres", dir. M.-O. Goulet-Caze, Paris, 1999, p. 382-386. - Quintiliano escreve que os autores que se contentaram com a divisão em três gêneros (isto é, quase todos), fizeram-no "seguindo Aristóteles" (Aristotelen secuti: Istituição oratória, III, 4, 1). Essa expressão não é um posicionamento sobre a questão de saber se Aristóteles era original ou não. Ela significa simplesmente que Quintiliano estava na mesma situação que nós e não conhecia texto anterior a Aristóteles em que aparecesse a tripartição dos gêneros tal como a apresenta Aristóteles.

21 Reclassificação trabalhada pela problemática filosófica, em torno das noções de privado e de público, de tempo, de fim, em torno da definição da felicidade, da política... Mas essa é uma outra história.

PERNOT, Laurent. Aristote et ses devanciers. Pour une archéologie du discours délibératif.

RÉSUMÉ: On étudie ici les origines de la classification des genres de discours (genre délibératif, genre judiciaire, genre épidictique) telle que la présente Aristote dans la Rhétorique, et particulièrement ce qui concerne la définition du genre délibératif par rapport aux autres genres. A cette fin sont examinés des textes de Thucydide, Platon, Isocrate et de la Rhétorique à Alexandre, dans lesquels apparaissent des classements et des critères qui préfigurent ceux d'Aristote. Cette enquête permet de reconstituer le contexte intellectuel de la Rhétorique et de mieux cerner la manière dont Aristote a travaillé pour composer ce traité, opérant une systématisation à partir de notions et de problèmes préexistants.

MOTS-CLEFS: genres de discours; genre déliberatif; Rhétorique d'Aristote. 